\title{
Phenotypic Variability and Anticipation in a Family of D178N-Familial Creutzfeldt-Jakob Disease
}

\section{Alfred Stenwin Sunny ${ }^{1}$, Albert Stezin ${ }^{2}$, Bala Balaji $V^{2}$, Nataraja $P^{2}$ and Naveen Thota ${ }^{2 *}$}

${ }^{1}$ Bioinformatics Specialist, Calpine technologies, Kerala, India

${ }^{2}$ Consultant, Department of Neurological Sciences, ANU Institute of Neuro and

Cardiac Sciences, Andhra Pradesh, India

*Corresponding Author: Naveen Thota, Senior Consultant, Department of Neurological Sciences, ANU Institute of Neuro and Cardiac Sciences, Andhra

Pradesh, India.
Received: February 17, 2021

Published: March 20, 2021

(C) All rights are reserved by Naveen Thota., et al.

\begin{abstract}
Familial Creutzfeldt-Jakob disease (fCJD) is caused by mutation in PRNP gene. The D178N variant of CJD is known to have phenotypic variability and can often mimic other neurological disorders. In this article, we report a family with D178N variant of PRNP mutation with phenotypic variability and anticipation phenomenon.
\end{abstract}

Keywords: Anticipation; Creutzfeldt-Jakob Disease; D178N; CJD: Phenotype Variability

\section{Abbreviations}

fCJD: Familial Creutzfeldt-Jakob Disease; AAO: Age at Onset; MRI: Magnetic Resonance Imaging; FLAIR: Fluid Attenuated Inversion Recovery; PSWC: Periodic Slow Wave Complex; CSF: Cerebrospinal Fluid

\section{Introduction}

Familial Creutzfeldt-Jakob disease (fCJD) is a rare entity and accounts for $10 \%$ of all CJD [1]. More than 40 different variants of the PRNP gene are known to cause familial CJD [1]. These are mostly nonsense, missense, octapeptide repeat insertion or deletion mutations [1]. Anticipation in the age at onset (AAO) has never been conclusively proven nor refuted in CJD. However, the D178N variant of CJD is known to be associated with phenotypic variability in the age at onset, clinical symptoms, and investigation findings $[1,2]$. In this article, we report a family with D178N-fCJD with apparent anticipation.

\section{Case Report}

The proband is a 38 year-old gentleman who presented with rapidly progressive memory disturbance, slurred speech, slowness in activities, seizures, decreased sleep, emotional lability, anxiety and depression of two months duration. On clinical examination, he had generalized bradykinesia, dysarthria, asymmetrical postural tremor of the upper limbs, and cognitive impairment (Montreal Cognitive Assessment score: 19/30).

An initial blood screen, including routine haematology, biochemistry, thyroid function, vitamin B12, serology for neurosyphilis, paraneoplastic antibodies, genetic analysis for trinucleotide disorders (SCA1,2,3,6,7,10,17) were normal. MRI brain revealed T2 and FLAIR hyperintense signals in the bilateral basal ganglia and thalamus. The DWI sequences demonstrated the characteristic hyperintense 'cortical ribbon sign' (Figure 1). Electroencephalogram showed slowing and periodic discharges with triphasic sharp wave 
complexes (PSWC). Exome sequencing revealed heterozygous, missense variation (c.532G>A, p.D178N) in the exon 2 of the PRNP gene (ENSG00000171867) with 129MV polymorphism. This variant has previously been reported as a pathogenic variation in CJD [3]. Sanger sequencing also confirmed the presence of the variant in the proband and his asymptomatic younger brother. CSF test was not performed due to a lack of consent. A final diagnosis of fCJD was established.

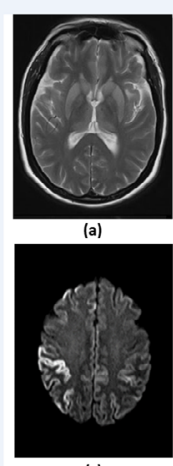

(c)

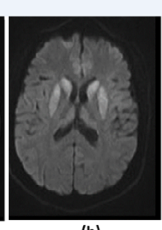

(b)
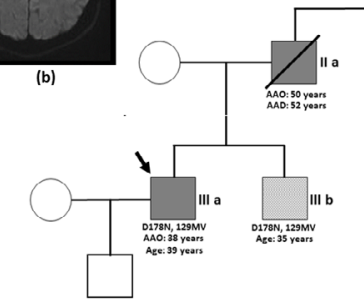

(d)
Figure 1a to 1c: Demonstrates the MRI changes in proband

IIIa. Figure 1(a) demonstrates hyperintense signals in bilateral caudate and putamen in axial T2 sequence. Figure 1(b) demonstrates hyperintense signals in bilateral caudate, putamen and thalamus in axial FLAIR sequence. Figure 1(c) demonstrates hyperintense signals predominantly in the right frontal, parietal and occipital cortices (cortical ribboning sign) in axial DWI sequence. Figure 1(d) demonstrates the autosomal dominant inheritance pattern of the disease in the family. Square $=$ male; circle $=$ female; diagonal blackline $=$ deceased; grey filled symbol = affected; light grey symbol = presymptomatic; empty symbol = clinically healthy relative; black arrow = proband; $\mathrm{AAO}=$ age at onset of symptoms; $\mathrm{AAD}$ $=$ age at demise.

Family history of neurological symptoms was present in the father, paternal grandfather, aunt, and cousin. The medical records of these individuals was evaluated for their symptoms and AAO. Significant heterogeneity was present in clinical features and their provisional diagnosis of different family members (Table 1). The provisional diagnosis considered included familial dementia, spinocerebellar ataxia, and Huntington's disease. The symptoms were rapidly progressive and was invariably fatal in all subjects within a span of one to two years.

\section{Discussion and Conclusion}

Clinical variability has been previously reported in patients with D178N-fCJD [1,3]. It is known that on the basis of polymorphism at codon 129 , patients may present either as familial fatal insomnia or fCJD [1,2]. Variable symptoms such as cognitive impairment, cerebellar signs, extrapyramidal symptoms, pyramidal signs, autonomic dysfunction, seizures, and psychiatric symptoms are known in D178N-fCJD variant [1,2]. Supplementary table 1 highlights the phenotypic variability in different members of the family. The imaging, EEG, and CSF 14-3-3 protein positivity is also variable in the D178N-fCJD variant [1,2].

Another notable observation was the presence of apparent anticipation in the AAO across three generations. A cursory review of previous reports on D178N-fCJD also demonstrates variability and an apparent anticipating trend in the AAO [2,3]. However, anticipation has never been truly established in the D178N-fCJD variant. Interestingly, anticipation was previously reported in terms of AAO and AAD (age at death) in the E200K-fCJD. However, Minikel., et al. demonstrated that the detected anticipation in the AAD of E200KfCJD was most likely due to statistical ascertainment bias [4]. One of the major reasons for the disrepute of anticipation in CJD is probably due to the traditional view that anticipation is either due to the expansion of unstable repeats or telomere shortening [5]. The absence of such a genetic phenomenon in CJD may portend the possibility of anticipation in CJD. The role of epigenetic factors underlying the molecular mechanisms of the onset of disease at a specific age is now recognized and apparent anticipation has been described in a multitude of disorders [5].

Notwithstanding the absence of absolute proof of genetic anticipation in CJD, many pedigrees demonstrate a trend of apparent anticipation. Although this may be due to a reporting or documentation bias, it still has a significant implication on genetic counselling in at-risk and asymptomatic individuals. Furthermore, in the absence of the typical CJD features, the presence of apparent an- 


\begin{tabular}{|c|c|c|c|c|c|c|}
\hline & Ia & IIa & Ilb & Illa & IIIb & IIIc \\
\hline Age at demise & 75 years & 52 years & 55 years & - & - & 41 years \\
\hline $\begin{array}{l}\text { Cognitive } \\
\text { impairment }^{1}\end{array}$ & $\begin{array}{c}\text { Dementia } \\
\text { MMSE = } 18\end{array}$ & $\begin{array}{l}\text { Dementia } \\
\text { MMSE = } 9\end{array}$ & Forgetfulness\# & $\begin{array}{l}\text { Dementia } \\
\text { MOCA = } 19\end{array}$ & $\begin{array}{c}\text { No impairment } \\
\text { MOCA }=30\end{array}$ & Forgetfulness\# \\
\hline $\begin{array}{l}\text { Psychiatric symp- } \\
\text { toms }\end{array}$ & - & $\begin{array}{c}\text { Hallucination } \\
\text { Depression }\end{array}$ & 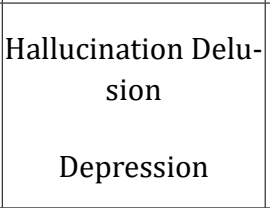 & $\begin{array}{c}\text { Irritability } \\
\text { Emotional lability } \\
\text { Depression, Anxiety }\end{array}$ & - & - \\
\hline Seizures & - & - & - & $\begin{array}{l}\text { Generalized tonic-clonic } \\
\text { seizure }\end{array}$ & - & - \\
\hline Cerebellar signs & - & - & $\begin{array}{c}\text { Ataxia } \\
\text { Incoordination }\end{array}$ & - & - & - \\
\hline $\begin{array}{l}\text { Provisional } \\
\text { diagnosis }\end{array}$ & $\begin{array}{l}\text { Alzheimer's } \\
\text { disease }\end{array}$ & $\begin{array}{l}\text { Familial } \\
\text { dementia }\end{array}$ & $\begin{array}{l}\text { Spinocerebellar } \\
\text { ataxia? type }\end{array}$ & Creutzfeldt Jakob disease & $\begin{array}{c}\text { Creutzfeldt } \\
\text { Jakob disease }\end{array}$ & $\begin{array}{c}\text { Genetic } \\
\text { parkinsonism }\end{array}$ \\
\hline
\end{tabular}

Table 1: Phenotypic variability and apparent anticipation in the members of the family.

1: Formal neuropsychological test data was available only in subjects IIIa (proband) and IIIb (asymptomatic brother). Patient IIIa had impairment in executive function, complex attention, perceptual motor function, learning and memory domains. Proband IIIb had no cognitive impairment in detailed neuropsychological evaluation. \# No formal testing done.

ticipation in the pedigree may lead the diagnostic process astray as portrayed by the provisional diagnosis of the family members in this case report.

Hence, further research should clarify the molecular mechanisms responsible for the determination of AAO and anticipation. Clinicians should also keep this conundrum in mind while evaluating patients with rapidly progressive cognitive disorder associated with abnormal movement disorders.

This manuscript was prepared following the ethical norms after written consent from subjects.

\section{Conflict of Interest}

The authors report no conflicts of interest.

\section{Bibliography}

1. Kim MO., et al. "Genetic PrP prion diseases". Cold Spring Harbor Perspectives in Biology 10 (2018): 1-45.

2. Zarranz JJ., et al. "Phenotypic variability in familial prion diseases due to the D178N mutation". Journal of Neurology, Neurosurgery and Psychiatry 76 (2005): 1491-1496.

3. Sawal N., et al. "Familial Creutzfeldt-Jakob disease: The first reported kindred from South-East Asia". Annals of Indian Academy of Neurology 22 (2019): 225-227. 
4. Minikel EV., et al. "Age at onset in genetic prion disease and the design of preventive clinical trials". Neurology 93 (2019): E125-

E134.

5. Petronis A., et al. "Genetic anticipation: Fact or artifact, genetics or epigenetics?”. Lancet 350 (1997): 1403-1404.

\section{Assets from publication with us}

- Prompt Acknowledgement after receiving the article

- Thorough Double blinded peer review

- Rapid Publication

- Issue of Publication Certificate

- High visibility of your Published work

Website: www.actascientific.com/

Submit Article: www.actascientific.com/submission.php

Email us: editor@actascientific.com

Contact us: +919182824667 